\title{
LATIN POLYPHONY IN THE EARLY SPANISH BAROQUE: SUGGESTIONS FOR STYLISTIC CRITERIA ${ }^{1}$
}

\author{
Judith ETZION \\ Bar-Ilan University, Israel
}

\begin{abstract}
This article focuses on the principal stylistic features in selected Latin works by Mateo Romero (Maestro Capitán), in order to suggest some basic guidelines for the generic and stylistic diversity of the Latin corpus in the early Spanish baroque. It essentially demonstrates how, on the one hand, Romero's contrapuntal works in the supposedly 'estilo antiguo' are substantially modified, and how, on the other, traditional features are retained within his works in the 'new style'. A special emphasis is given to Romero's polychoral works, which exemplify the most 'progressive' polychoral trend in the early Spanish baroque.
\end{abstract}

\section{Resumen}

El presente artículo se centra en los rasgos estilísticos principales de determinadas obras con texto latino de Mateo Romero (Maestro Capitán), en relación al estudio de algunas pautas básicas dentro de la diversidad genérica y estilística del corpus latino del barroco español temprano. El trabajo demuestra esencialmente cómo, por una parte, las obras contrapuntísticas de Romero, escritas en el supuestamente llamado "estilo antiguo" están substancialmente modificadas, y, por otra, cómo los rasgos tradicionales se hallan comprendidos en sus obras escritas en el "nuevo estilo". Se pone especial interés en las obras policorales de Romero para ejemplificar la tendencia más progresiva del estilo policoral en el barroco español temprano.

The purpose of this presentation is to stimulate a comprehensive stylistic inquiry into the immense corpus of Latin polyphonic works composed in Spain during the early baroque. Although baroque composers were fully aware of, and indeed complied with, the general categories of the estilo antiguo and estilo moderno, in practice they were neither schematic nor conclusive. As compositional processes, by and large, thrive on the tension between tradition and novelty, the perpetuation of the 'old style' in the Spanish baroque should not be viewed as a mere antiquarian phenomenon, but rather as a "baroque re-interpretation of renaissance music."

1. This paper elaborates on some of the observations made in my critical edition of Mateo Romero (Maestro Capitán). Collected Latin Works, 5 vols., Corpus Mensurabilis Musicae, ser. 109 (American Institute of Musicology, Hänssler-Verlag, 2001). Refer to the edition for the complete list of sources, critical notes, and bibliography.

2. Manfred Bukofzer, Music in the Baroque Era from Monteverdi to Bach (New York: W.W. Norton, 1947 ), p. 70.

Anuario Musical, 56 (2001) 
Inversely, the 'modern' (or 'new') baroque style cannot be properly evaluated without taking into account the preservation of traditional topoi.

Although some insightful observations regarding the style of Latin polyphony during the early Spanish baroque appear in studies of seventeenth-century Spanish music, no systematic comparative analysis has been undertaken yet to explore the generic and stylistic diversity in the Latin corpus of, at least, the leading composers of the period. I have therefore chosen to concentrate on principal characteristics in selected Latin works by Mateo Romero (Maestro Capitán), in order to suggest some basic stylistic guidelines.

Maestro Capitán was one of the dominant musical figures in Spain during the first three decades of the seventeenth century, due to his prestigious status as composer, maestro de capilla at the royal chapel, and director of many musical activities at the Madrid court. ${ }^{3}$ Considered as the last prominent composer of the so-called 'Flemish School', he essentially followed the path of Philippe Rogier, his predecessor as maestro de capilla and mentor (d.1596). Since the majority of works by Capitán's Flemish contemporaries at the Spanish royal chapel have not survived, and those that are extant have hardly been transcribed and studied, it remains uncertain to what degree his style differs from theirs. ${ }^{4}$ It appears, though, that he exhibits a particularly resourceful handling of the antiphonal choirs in the polychoral works, a more daring approach to dissonance treatment, and a highly expressive musical depiction of the Latin texts. His Latin works apparently became a stylistic model for many Spanish composers of subsequent generations.

As will be shown below, Capitán introduces new stylistic ideas into his works in the 'old style' and, vice versa, retains traditional features within his works, mostly polychoral works, in the 'new style'. In addition, he occasionally incorporates popular idioms associated with Spanish secular music and the villancicos. This brief survey, consequently, will hopefully offer some viable stylistic criteria for the evaluation of Latin works by other composers of the early Spanish baroque.

Considering the predominant role of the Catholic institutions as musical patrons in Spain, the polyphonic tradition of the renaissance was naturally perpetuated in the Spanish capillas more than in any other European country. Among Capitán's extant works still adhering to it are one short ferial mass in fabordón and three parody masses: Missa Batalla a 4, Missa 'Sabbato Sancto' a 4, and Missa 'Dolce Fiammella mia' a 5. ${ }^{5}$ As would be expected, the parody masses contain duple mensuration with shifts to triple proportion in specific sections (e.g., the Hosanna), predominantly imitative texture, and the traditional heightening of

3. For a biographical study of the composer see Paul BECQUART, Musiciens néerlandais à la cour de Madrid. Philippe Rogier et son école (1560-1647) (Brussels: Palais des Académies, 1967), pp. 145-214.

4. See ibid. for the biographies and list of works of the leading Flemish composers at the Madrid royal chapel (notably Philippe Rogier, Englebert Turlur, Andrien Capy, Géry de Ghersem, Jean de Namur, Philippe Dubois, and Nicolas Dupont). In addition to Latin works, they composed numerous villancicos, as well as Spanish polyphonic artsongs (tonos) and French chansons. The only modern edition of the collected works of any of these composers is Philippe Rogier. Opera Omnia, ed. Lavern Wagner, 3 vols., Corpus Mensurabilis Musicae, ser. 61 (American Institute of Musicology, 1974-76).

5. These masses appear in Vol. II of the critical edition. 
significant textual lines by means of longer note values (e.g., "Jesu Christe", "Ex Maria Virgine", "Crucifixus") or word-painting on key words or phrases (e.g., "descendit", "ascendit", "Et incarnatus est", "resurrectionem mortuorum"). None of these masses, however, would be mistaken for a sixteenth-century work, not even the fabordón mass, since they all deviate from the contrapuntal precepts of the ars perfecta. Missa 'Sabbato Sancto' and Missa 'Dolce Fiammella mia', in particular, may be defined as 'manneristic' works, due to the frequency of unconventional intervalic leaps in all the voices, 'anomalous' alterations, defiance of the musica ficta rules, unprepared dissonances, and 'wrong' resolutions of suspensions. These characteristics generate, in addition, passages of bizarre chordal sonorities, which occasionally recall even the Italian durezze style. It is therefore not surprising that the composer's proficiency in contrapuntal techniques was questioned at the time. ${ }^{6}$ In view of his indisputable contrapuntal mastery as a whole, it appears that this 'manneristic' style was deliberate.

The three parody masses, furthermore, display diverse techniques of borrowing. For example, Missa 'Batalla' focuses on the head motif of Janequin's La guerre and freely elaborates the chanson's parlando passages, fanfare sections, and shifts from duple to triple mensurations. Missa 'Sabbado Sancto' might have been based on Duarte Lobo's Missa 'Hic est vere Martyr', which in turn is a parody of Palestrina's motet; and Missa 'Dolce fiammella mia' paraphrases a madrigal by Giovanni Maria Nanino, whose opening and closing phrases, as well as cadential points, serve as the framework for the mass movements. How the estilo antiguo is approached in masses by other Spanish composers of the early baroque remains to be examined. They certainly deserve an extended study. ${ }^{7}$

The majority of Capitán's surviving Latin works in the 'new style' are polychoral. ${ }^{8}$ Before explaining the nature of this compositional novelty, a brief introductory comment on Spanish polychorality in general would be appropriate. Polychorality, to begin with, is not a "Spanish invention", as some Spanish musicologists naively believe. Needless to say, polychoral music - namely, music for two or more split choirs which are essentially independent and treated in antiphonal manner (rather than as many-voiced polyphony) - was already written by Franco-Flemish and North Italian composers in the 1520 s. $^{9}$ From the middle of the sixteenth century onward its practice expanded substantially, especially in Italy and Germany-Austria. Although Spanish composers of the late sixteenth and early seventeenth centuries were familiar with the polychoral works of Orlando di Lasso and contemporary

6. For details see ibid., p. 9.

7. For some insightful notes on the estilo antiguo masses by Juan Bautista Comes, see the recent edition of Juan Bautista Comes. Masses, ed. Greta J. OLSON (Madison: A-R Editions, 1999), Part 1, pp. ix-xi.

8. Only a handful of his extant Latin works in the new style are for one choir; see Vol. IV in the critical edition. Needless to say, this new style in Latin polyphony does not necessarily coincide with all the criteria of the Italian 'stile moderno', as associated with the late Italian madrigal or the music theater at the turn of the seventeenth century.

9. A historical outline of polychorality is beyond the present limits. A comprehensive survey appears in Anthony F. CARver, Cori spezzati. The development of sacred polychoral music to the time of Schütz, 2 vols. (Cambridge: Cambridge University Press, 1988). It contains an extensive bibliography and a separate volume of musical examples. 
composers of the Venetian and Roman Schools, ${ }^{10}$ no study has defined yet the precise stylistic links between Spanish and European polychorality. Victoria's polychoral works, which essentially emulate and modify the style of the Roman School, are so far the earliest accessible Spanish compositions complying with the above stylistic definition. ${ }^{11}$ Numerous Latin polychoral works by other Spanish-born composers of the early seventeenth century, some of which have been published in modern editions, need to be studied in detail (e.g., by Alonso Lobo, Pedro Ruimonte, Bernardo Clavijo del Castillo, Juan Pujol, Sebastián López de Velasco, Sebastián Aguilera de Heredia, Sebastián de Vivanco, and Juan Bautista Comes). They represent a wide variety of compositional approaches to polychorality, ranging from essential compliance with sixteenth-century counterpoint to the more 'progressive' trend of highly resourceful antiphonal techniques in a primarily homorhythmic texture. In addition, the reciprocal influences between the polychoral techniques in the Latin works and the numerous villancicos of the period should be closely examined.

Capitán's polychoral works exemplify the 'new style' of Latin polyphony in the early Spain baroque and its association with the sumptuous liturgical events in the principal capillas during the Counter-Reformation. Among them, his three masses, three magnificats, and five psalms are briefly treated here. These works exhibit, first and foremost, preponderance of homorhythmic, block-like chordal texture (referred to as "consonancias" at the time), harmonically independent choirs, freer dissonance treatment, abundant antiphonal techniques, and basso seguente or basso continuo for each choir. The participation of diverse instruments in their performance was apparently prevalent, although they were not necessarily specified in the musical sources. The organ, bajon, harp, or any other available low string instrument, were employed for the continuo parts, as well as for substitution or duplication of the vocal basses. Other instruments may have additionally duplicated higher voices. (Many of the above features are already encountered in Rogier's polychoral works.)

Capitán's Missa 'Un jour l'amant' a 8, Missa 'Qui habitat' a 8, and Missa 'Bonae voluntatis' (in five- and nine-part versions) have survived in numerous copies well into the nineteenth century, thus attesting to the enduring stylistic relevance of the early seventeenthcentury polychoral style in general, and to the perseverance of the high esteem for Capitán in particular. ${ }^{12}$ At the same time, these masses continue to maintain traditional generic features: they are all parody masses containing diverse paraphrasing techniques; they still tend to preserve imitative entrances in the Kyrie, Gloria and Agnus Dei; and they accentuate significant textual lines by the same musical devices as in the estilo antiguo masses, albeit in a more extended manner due to the antiphonal nature of the choirs.

10. BeCQuart, op.cit., passim.

11. The eight-part works by composers such as Cristóbal de Morales, Francisco Guerrero, and Fernando de las Infantas are not, properly speaking, polychoral works.

12. For further details on these masses see Vols. I/1 and I/2 of the critical edition. 
Missa 'Un jour l'amant' is chronologically the earliest among Capitán's extant polychoral masses (c1605), and also the most 'conservative' one. Based on Orlando di Lasso's eight-part chanson, it retains many of the model's phrases intact, including the phrasal order and cadential points (with emphasis on the outer phrases). These lyrical phrases further alternate with short antiphonal exchanges based on their motivic fragments. The mass frequently introduces short imitative entrances and long ornate passages, which are not encountered to that degree in the later masses. That the two choirs are not entirely independent harmonically is likewise indicative of an early phase in the composer's polychoral writing.

Missa 'Qui habitat' not only exhibits a much freer and resourceful motivic manipulation of its model (the composer's own psalm), but also a clear-cut division into two independent and well-balanced choirs, fast antiphonal dialogues, long passages of repeated harmonic sonorities, sectional contrasts, and a salient tonal sense of ' $G$ major'. These attractive qualities may explain the particularly wide diffusion of this mass until the nineteenth century, including 'updated' arrangements even for a modern orchestra. ${ }^{13}$

The two versions of Missa 'Bonae voluntatis' represent yet another compositional approach, which suggests a possible influence of the contemporary villancicos. First, it introduces a high solo voice with its proper continuo part (i.e., solo + CATB in the five-part version, and solo + CATB CATB in the nine-part version). ${ }^{14}$ Second, although it is constructed as a parody mass, it is doubtful whether it was based on any specific model (no Latin work is known as "Bonae voluntatis"). The title of the mass was probably derived from the numerous choral repetitions of "bonae voluntatis" (followed by "miserere nobis") in the Gloria, which serve as a quasi-responsory to the lyrical solo part containing the remainder of the text. An identical treatment appears in "miserere nobis" and "dona nobis pacem" in the Agnus Dei. An additional noteworthy feature is the poignant, two-chord invocation of the word "Credo" throughout the Credo movement, which recalls similar invocations in much later stylistic periods. Third, the mass (with the exception of the Kyrie) is permeated by popular features, typical of secular songs and villancicos, such as the Phrygian descending tetrachord, leaps of fourths in the bass, and lively rhythmic patterns. ${ }^{15}$

Stylistically, Capitán's magnificats and psalms do not essentially differ from his polychoral masses, aside from their traditional generic exigencies. ${ }^{16}$ In the magnificats the practice of alternating whole or half verses between the two choirs is still evident, although it soon dissolves into lively antiphonal exchanges of repeated fragmental phrases, often in a parlando fashion. Furthermore, the traditional practice of using the magnificat tone as a

13. For example, one source of the mass in Santiago de Compostela, dating from the late eighteenth or early nineteenth century, contains violin I \& II, flute, clarinet I \& II, and trompas, all duplicating more or less the vocal parts.

14. Generally, such works for five and nine parts are divided into two and three coros, respectively, in which the first coro corresponds to the solo vocal part and its continuo.

15. Capitán's Letanía de Nuestra Señora for solo and CATB (Vol. IV in the critical edition) shows a close resemblance to this mass, suggesting that it might have conceivably served as its parody model. They have a similar interplay between the solo and choir as well as the same autochthonous popular features.

16. See Vol. III in the critical edition. 
framework for mediant and sectional cadences, as well as its paraphrasing throughout the setting, is retained. Words of a particular emotive significance may also be accentuated by longer notes, suspensions, or frequent repetition (e.g., "recordatus misericordiae suae"). Finally, the opening of the doxology is set to both choirs in longer notes, followed by two or more sections of various antiphonal techniques. One magnificat, however, is stylistically exceptional in Capitán's entire polychoral corpus. Its proporción menor (C3), highly intricate rhythms (resulting from the backand-forth shifts to coloration), predominantly imitative texture, and numerous suspensions and unprepared dissonances are all characteristic of the composer's expressive madrigalian artsongs (tonos). ${ }^{17}$

Capitán's extant polychoral psalms for Vespers (Dixit Dominus and Laudate Dominum omnes gentes) and Compline (two different settings of Cum invocarem and one of Qui habitat) are essentially similar to the magnificats, including the doxology (except for the setting in proporción menor mentioned above). They exhibit, however, greater antiphonal diversity, depending on their degrees of proximity to, or departure from, the sixteenth-century conventions of polychoral psalm settings. They may introduce, on the one extreme, the traditional practice of antiphonal exchanges of whole or half verses in imitative texture, and, on the other, the more recent trend of fast dialogues of chordal, fragmental phrases with multiple word repetition. In addition, the expressive musical highlighting of changing moods and images in the psalm verses is conspicuous in these settings. ${ }^{18}$

In conclusion, the following questions should be posed in evaluating the generic and stylistic aspects of Latin polyphony of the early Spanish baroque:

- Which types of liturgical texts were most susceptible to composition in the so-called 'estilo antiguo' and 'estilo moderno'? To what degree was it dictated by local traditions, the number of available singers, or by the exposure of the individual capillas to recent stylistic trends?

- What types of modifications were introduced into the traditional contrapuntal rules in Latin works composed supposedly in the 'old style' (i.e., in terms of dissonance treatment, imitative techniques, melodic contour, alterations, etc.)?

- What were the prevalent types of borrowing models (e.g., motets, Spanish and French songs) in the parody masses? To what extent did such masses follow, modify, or departure from sixteenth-century conventions? Did the paraphrasing techniques differ in masses composed in the 'old' or 'new' styles? How did both traditional and novel characteristics shape the generic identity of Latin works other than the mass?

- How was Latin polyphony distinguished stylistically from the Spanish secular genres and the villancicos and, at the same time, influenced by them?

17. See particularly nos. 13 and 36 in the Cancionero de la Sablonara. A Critical Edition, ed. Judith Etzion (London: Tamesis, 1996).

18. An extraordinary example is the choral falseto followed by a soloist on "dormian et requiescam" in the second Cum invocarem setting. See Vol. III of the critical edition. 
- How was Spanish polychorality linked to polychoral trends abroad, especially in Italy? To what extent did the polychoral works by Victoria and the Flemish composers active at the Madrid royal chapel serve as a stylistic model for contemporary and subsequent generations of Spanish-born composers? Undoubtedly, a genuine school of Spanish polychorality did emerge at the turn of the seventeenth century. Can specific trends of Spanish polychorality be discerned beyond the stylistic idiosyncrasies of the individual composers? 